\title{
Ti含有フェライト系ステンレス鋼の凝固組織に及ぼす 酸化物組成の影響
}

\author{
藤村 浩志* ·柘植 信二* . 小溝 裕一 * ·西澤 泰二* \\ Effect of Oxide Composition on Solidification Structure of Ti Added Ferritic Stainless Steel \\ Hiroshi Fujimura, Shinji Tsuge, Yuichi Komizo and Taiji Nishizawa
}

\begin{abstract}
Synopsis : Effect of oxide composition on the solidification structure of $16 \mathrm{mass} \% \mathrm{Cr}-0.15 \mathrm{mass} \% \mathrm{Ti}-0.009 \% \mathrm{~N}$ ferritic stainless steel was investigated. As for the results, the oxides in steel ingots was observed to be covered by TiN and contained $\mathrm{Al}$ and $\mathrm{Mg}$. When the $\mathrm{Mg} / \mathrm{Al}$ mass ratio of oxides, determined by EDS analysis, ranged from 0.3 to 0.5 , an equiaxed fine-grain structure was produced. According to $\mathrm{Al}_{2} \mathrm{O}_{3}-\mathrm{MgO}_{\text {phase dia- }}$ gram, the oxide composition range corresponds with Spinel phase composition at molten steel temperature. And the disregistry between Spinel and TiN is very low. Therefore, it is presumed that the particles of Spinel accelerate the formation of TiN in molten steel and then an equiaxed fine-grain structure is produced. The mechanism of Spinel dispersion in molten steel is discussed on the information of phase diagram for $\mathrm{Al}_{2} \mathrm{O}_{3}-\mathrm{MgO}-\mathrm{TiO}_{2}$ system and the nucleation theory. It is speculated that the spontaneous nucleation of liquid $\mathrm{Al}-\mathrm{Mg}-\mathrm{Ti}$ oxide occurs due to low interfacial energy with molten steel and then the oxide droplets grow into Spinel.
\end{abstract}

Key words: equiaxed crystal; homogeneous nucleation; inclusion; ridging; slag; spinel; TiN.

\section{1. 緒言}

SUS430 (16\%Cr) やSUH409L (11\%Cr) を代表とする Cr系 冷延鋼板は，プレス成型時にリジングいが発生する問題が ある。リジングは成型品の美観を損ねることはもちろん， それを起点に割れが発生する場合もある。リジングを防止 するには, 凝固組織の等軸晶微細化が有効であり, 電磁拀 找による方法 ${ }^{2}$ p Ti添加による方法 ${ }^{3}$ が報告されている。 この2つの方法を比較すると, Ti添加法の方が, 凝固組織 をより微細に制御できる点で優れている。しかしながら， その効果を十分得るために多量の Tiを添加すると溶鋼に 分散した TiNがクラスターを形成し連続鋳造時にタン

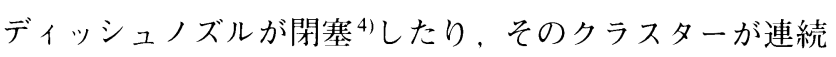
鋳造鋳片表層部に捕捉 ${ }^{5}$ され熱延, 冷延後の最終製品に表 面疵を誘発する問題が生じる。したがって, 鋼板のリジン グ並びに表面疵を抑制するには，より少ない Ti量での凝 固組織等軸晶微細化を指向する必要がある。フェライト系 ステンレス鋼の凝固組織を等軸晶微細化するために必要な Ti量については，いくつかの報告 ${ }^{3,6) か ゙ あ る 。 そ れ ら に よ ~}$ れば, $0.01 \% \mathrm{~N}$ 含有時には最低 $0.2 \%$ 以上の Ti量が必要と されてきた。

これに対し，筆者らは $\mathrm{Ti}, \mathrm{N}$ 量が同じでも凝固組織が柱 状晶となる場合と等軸晶となる場合があり， Ti, N 量のみ が等軸晶凝固の十分条件でないことを知見した。このよう な鋼の介在物としては, 酸化物を核に生成した TiNが分散
している。このことから，著者らは少ない Ti量でも酸化 物制御により TiN生成を促進させ， TiN 生成温度を鋼の凝 固開始温度以上にすれば凝固組織が等軸晶微細化すると考 えた。そこで本研究では, TiN生成促進に有効な酸化物組 成について調査し，さらにその酸化物の分散メカニズムに ついて考察した。

\section{2. 実験方法}

Table 1 に示す化学組成の 16\% Cr 鋼 $34 \mathrm{~kg}$ を真空溶解炉に より溶解し, 以降 $1600^{\circ} \mathrm{C}$ に保持した。その溶鋼を $50 \% \mathrm{CaO}-25 \% \mathrm{Al}_{2} \mathrm{O}_{3}-10 \% \mathrm{MgO}-15 \% \mathrm{CaF}_{2}$ の組成のスラグ 340 $\mathrm{g}$ で精錬した後, $\mathrm{Al}, \mathrm{Ti}$ を添加した。その際 $\mathrm{Al}$, Tiが溶鋼と 直接反応するように, 厚さ $0.1 \mathrm{~mm}$ の鉄箔に包み, 厚さ 5 $\mathrm{mm}$, 幅 $20 \mathrm{~mm}$, 長さ $150 \mathrm{~mm}$ の鋼板の先端に取り付け, そ の鋼板を溶鋼に浸漬させる方法を採った。次に, その溶鋼 の一部を内径 $22 \mathrm{~mm}$, 長さ $50 \mathrm{~mm}$ の石英管により採取し凝 固させた。酸化物組成を変化させるため, $\mathrm{Al}$ 添加量 （0.015\%, 無添加）や Al, Ti添加から溶鋼採取までの時間 （1１0 分）を種々変化させた。 $\mathrm{Al}, \mathrm{Ti}$ 添加量および溶鋼採 取の時期を Fig. 1 に示す。得られた鋳片より, 鋼中 Al（酸

Table 1. Chemical composition of molten alloy before slag addition. (mass $\%$ )

\begin{tabular}{ccccccccrr}
\hline $\mathrm{C}$ & $\mathrm{Si}$ & $\mathrm{Mn}$ & $\mathrm{P}$ & $\mathrm{S}$ & $\mathrm{Cu}$ & $\mathrm{Ni}$ & $\mathrm{Cr}$ & $\mathrm{Nb}$ & $\mathrm{N}$ \\
\hline \hline 0.005 & 0.15 & 0.15 & 0.02 & 0.001 & 0.30 & 0.15 & 16.5 & 0.25 & 0.009 \\
\hline
\end{tabular}


可溶 $\mathrm{Al}$ ），Ti，O およびN成分分析，鋳片の端から $15 \mathrm{~mm}$ 離 れた丸断面の凝固組織観察，および同断面をダイヤモンド 研磨してから酸化物組成の EDS 分析を行った。さらに， 同断面の中心から $5 \mathrm{~mm}$ 離れた $1 \mathrm{~mm}$ 四方の領域にある Ti成 分の分布を EPMAにより分析し，TiNの分散密度を測定し た。測定条件は，電圧 $20 \mathrm{kV}$, 電流 $0.15 \mu \mathrm{A}$ ，一測定時間 $0.05 \mathrm{~s}$, 分割数 $512 \times 512$ とした。

\section{3. 実験結果}

Table 2 には鋳片の Al, Ti，O, N 含有量を溶鋼から採取し た順に示す。 $\mathrm{Al}$ 量は 0.005 0.019\%の範囲にあり，Ti量は 狙い通り $0.15 \sim 0.18 \%$ ，O，Nはそ扎ぞれ0.002\%,0.009\%で ほぼ一定である。Fig. 2 には同鋳片の凝固組織を示す。各

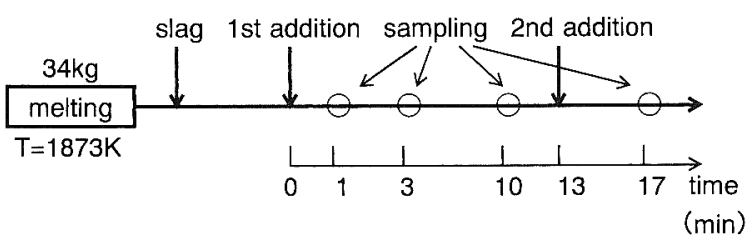

Contents of $\mathrm{Al}$ and $\mathrm{Ti}$ added into molten alloy.

\begin{tabular}{|c|c|c|c|c|}
\hline \multirow{2}{*}{$\begin{array}{c}\text { Test } \\
\text { No. }\end{array}$} & \multicolumn{2}{|c|}{ 1st addition } & \multicolumn{2}{c|}{ 2nd addition } \\
\cline { 2 - 5 } & $\mathrm{Ti}$ & $\mathrm{Al}$ & $\mathrm{Ti}$ & $\mathrm{Al}$ \\
\hline $\mathrm{A}$ & 0.20 & 0.015 & 0.015 & 0.015 \\
\hline $\mathrm{B}$ & 0.19 & - & 0.015 & 0.006 \\
\hline
\end{tabular}

Fig. 1. Schematic diagram of experimental procedure. Sample ingot is $22 \mathrm{~mm}$ in diameter, $50 \mathrm{~mm}$ in height.
鋳片のTi， N量がほぼ同じであるのにもかかわらず，等軸 晶凝固した鋳片もあれば，柱状晶凝固した鋳片も得られた。 EPMAによるTiNの分散密度測定は，柱状晶凝固した鋼 A4 と等軸晶凝固した鋼B3を対象に行った。その結果, 鋼 A4で 650 個 $/ \mathrm{mm}^{2}$ ，鋼 B3 で 560 個 $/ \mathrm{mm}^{2}$ とほぼ同等であった。 TiN 分散密度は凝固組織と関連があると予想されるが，測 定対象の TiNを凝固前後いずれの時期に生成したのか分離 できないので凝固組織との関連を議論することは難しい。

Fig. 3 に，鋳片断面で観察される典型的な介在物の反射 電子像，およびその介在物中央のEDS 分析結果を示す。 この介在物は内側に $\mathrm{Al}, \mathrm{Mg}$ 含含酸化物，外側にTiNの複 合構造を有している。そのさらに外側に $\mathrm{Nb}$ 炭窒化物が析 出している。ここで著者らは内側の酸化物組成を表す指 標として介在物の EDS 分析より得られた $\mathrm{Mg}, \mathrm{A} 1$ 量より $\mathrm{Mg} / \mathrm{Al}$ 重量比を計算し, $\mathrm{Mg} / \mathrm{Al}$ 比と凝固組織との関係を Fig. 4に整理した。今回の実験では, $\mathrm{Mg} / \mathrm{Al}$ 比が $0.1 か ら$ 0.5 まで変化した鋳片が得られ， $\mathrm{Mg} / \mathrm{A} 1$ 比 0.3 から 0.5 の場

Table 2. Chemical compositions and solidification structure of ingots.

\begin{tabular}{|c|ccccc|l|}
\hline Steel & $\mathrm{Ti}$ & $\mathrm{Al}$ & $\mathrm{O}$ & $\mathrm{N}$ & $\mathrm{Ti}^{*} \mathrm{~N}$ & solid. structure \\
\hline A1 & 0.174 & 0.015 & 0.0022 & 0.0094 & 0.00164 & Columnar grain \\
$\mathrm{A} 2$ & 0.168 & 0.016 & 0.0022 & 0.0096 & 0.00161 & Columnar grain \\
$\mathrm{A} 3$ & 0.152 & 0.013 & 0.0022 & 0.0095 & 0.00144 & Equiaxed grain \\
$\mathrm{A} 4$ & 0.164 & 0.019 & 0.0022 & 0.0094 & 0.00154 & Columnar grain \\
\hline B1 & 0.178 & 0.005 & 0.0023 & 0.0093 & 0.00166 & Equiaxed grain \\
B2 & 0.169 & 0.007 & 0.0021 & 0.0098 & 0.00166 & Equiaxed grain \\
B3 & 0.149 & 0.010 & 0.0016 & 0.0093 & 0.00139 & Equiaxed grain \\
B4 & 0.155 & 0.013 & 0.0020 & 0.0089 & 0.00140 & Columnar grain \\
\hline
\end{tabular}
(mass\%)

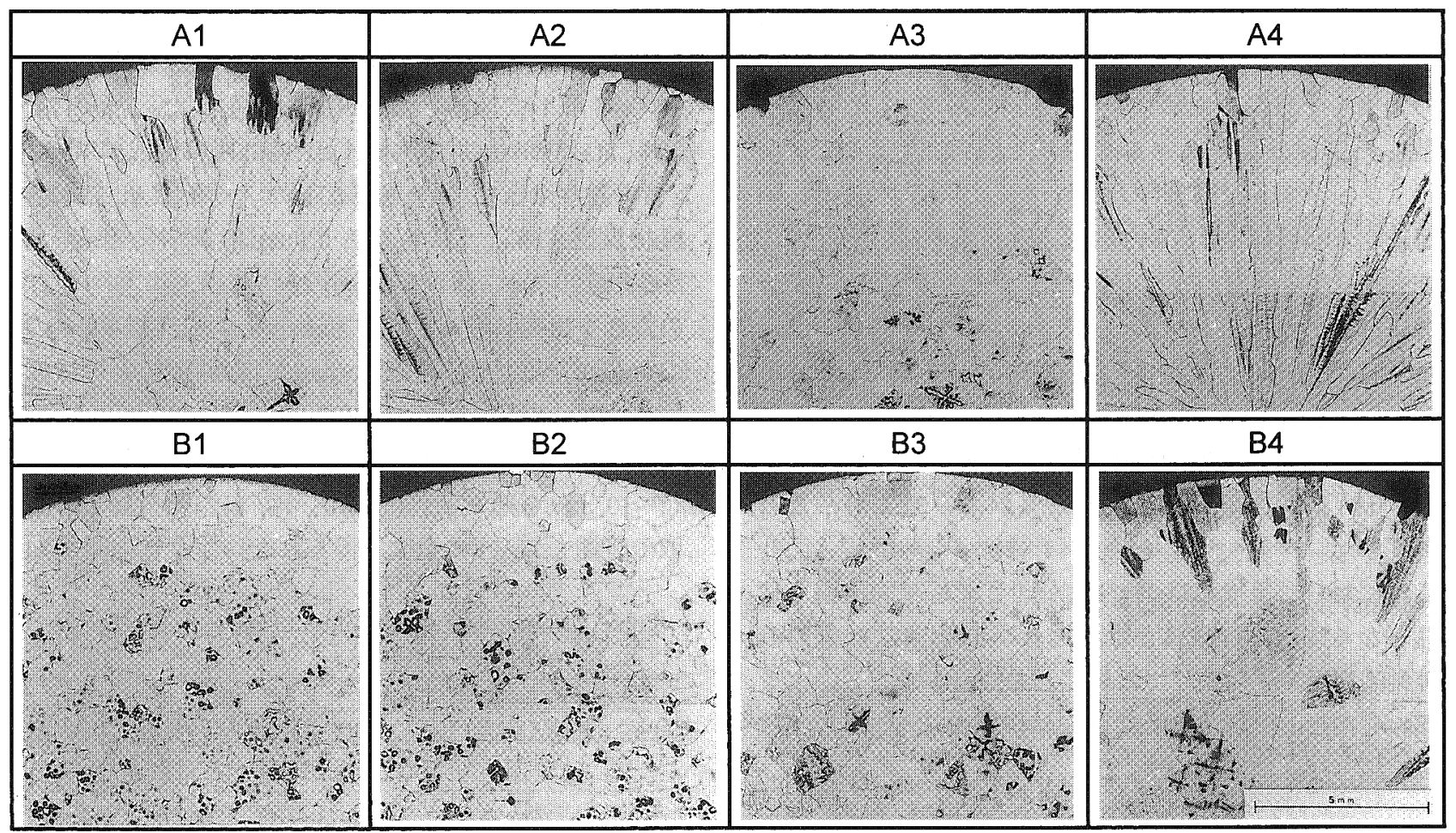

Fig. 2. Solidification structure of ingots. 


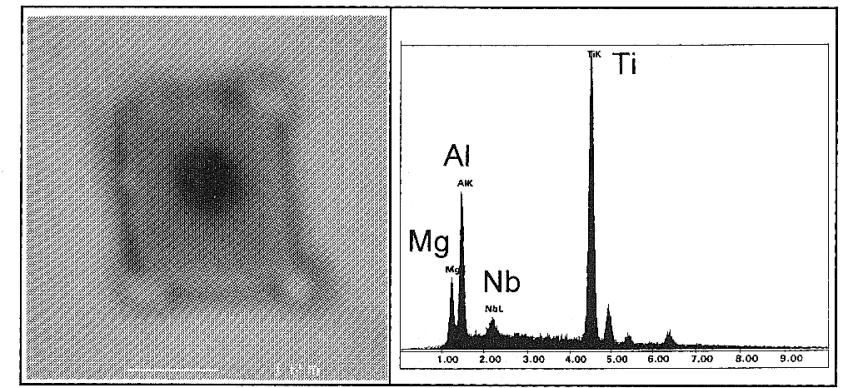

Fig. 3. Typical BSE image and EDS chart of an inclusion in B1 steel.

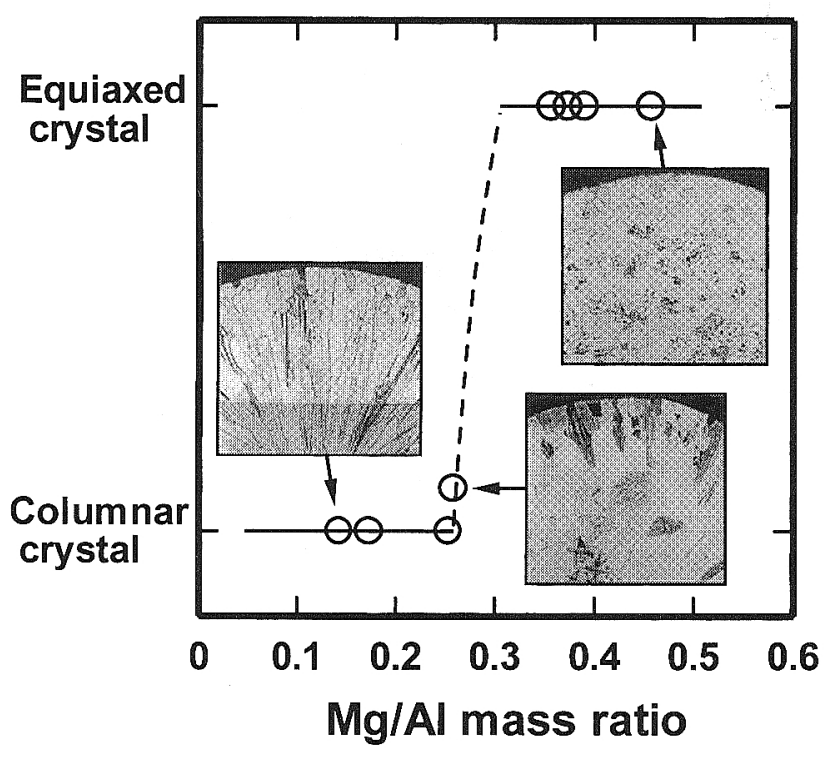

Fig. 4. Effect of oxide composition, $\mathrm{Mg} / \mathrm{Al}$ ratio, on solidification structure.

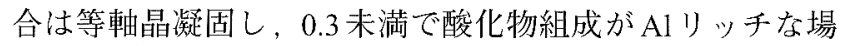
合は柱状晶凝固した。このように複合介在物の核に存在す る酸化物組成と凝固組織の間に明膫な相関がみられる。

$\mathrm{Al}, \mathrm{Mg}$ 含む酸化物には, Fig. $50 \mathrm{Al}_{2} \mathrm{O}_{3}-\mathrm{MgO}$ 二元系状 態図》で示すように, $\mathrm{Al}_{2} \mathrm{O}_{3}$ (Corundum), $\mathrm{MgOAl}_{2} \mathrm{O}_{3}$ (Spinel), $\mathrm{MgO}$ (Periclase)の3つの化合物相がある。この状態図より， 等軸晶凝固した鋳片に分散寸る酸化物の組成は, 溶鋼温度 におけるSpine1相の組成と一致する。また，脱酸生成物と して Spinelが生成することの妥当性を従来の報告 ${ }^{8,9)}$ と比較 して検討するため, 鋼 $\mathrm{A} 3$ に含まれる $\mathrm{Mg}$ 成分量を酸分解 法により分析した。結果, Mg 分析值は 1 mass ppm 以下と 分析限界以下であった。これより溶鋼中の $\mathrm{Mg}$ 活量を 0.1 から 1 mass ppm と仮定すれば，穴れは既存の Spinel生成領 域にほぼ一致する。本実験で酸化物組成が鋼に上り異なる のは, 溶鋼中の $\mathrm{Al}, \mathrm{Mg}, \mathrm{O}$ 活量のバランスが微妙に变化し たためと考光られる。

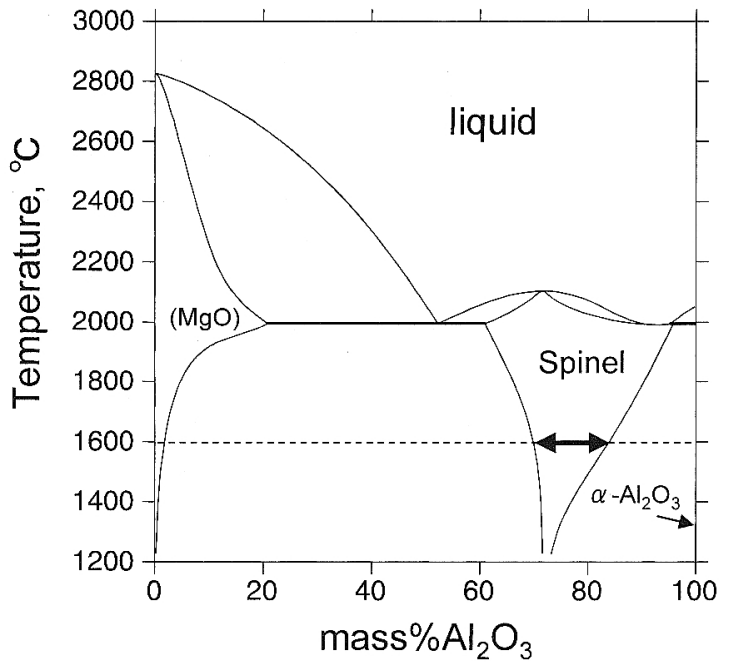

Fig. 5. Calculated phase diagram for $\mathrm{Al}_{2} \mathrm{O}_{3}-\mathrm{MgO}$ system. ${ }^{7}$

Table 3. Planar disregistry between $\delta \mathrm{Fe}$, TiN and inclusions.

\begin{tabular}{|ll|c|c|}
\hline \multicolumn{2}{|c|}{$\begin{array}{c}\text { Inclusions } \\
(\mathrm{nm})\end{array}$} & \multicolumn{2}{c|}{ Planar disregistry (\%) } \\
\cline { 3 - 4 } TiN & $\mathrm{a}=0.4244$ & 3.9 & - \\
\hline $\mathrm{MgO}$ & $\mathrm{a}=0.4211$ & 2.8 & 1.1 \\
\hline $\mathrm{Spinel}^{\mathrm{a}=0.8083}$ & 1.4 & 5.1 \\
\hline $\mathrm{Al}_{2} \mathrm{O}_{3}$ & $\begin{array}{c}\mathrm{a}=0.4759 \\
\mathrm{c}=1.2991\end{array}$ & 16.1 & 11.7 \\
\hline \multicolumn{3}{|c|}{$(\mathrm{a} \delta=0.2866 \mathrm{~nm})$} \\
\hline
\end{tabular}

\section{4. 考察}

\section{$4 \cdot 1$ 核生成物質}

少ない Ti, $\mathrm{N}$ 量にて TiN 鋼の凝固温度以上で晶出させ $\delta$ 鉄の凝固核とするには，有効なTiNの晶出核が存在すれば

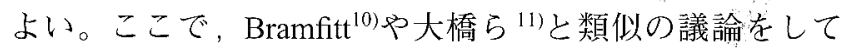
みる。彼らは， $\delta$ 鉄の凝固を促進するには， $\delta$ 鉄との結晶 不整合度が小さい粒子を溶鋼に導入することが有効である と実験的に示している。これと同様に，TiNと各種酸化物 との結晶不整合度について計算した結果を Table 3 に示す。 SpinelやMgOはTiNとの結晶不整合度が非常に小さいのに 対し， $\mathrm{Al}_{2} \mathrm{O}_{3}$ とのそれは大きい。したがって Spinelや $\mathrm{MgO}^{(2)}$ の酸化物粒子は TiNの晶出を促進するのに有効な核 である可能性がある。本実験の範囲では $\mathrm{MgO}$ について確 認されていないが，少なくとも SpinelがTiNの晶出を促進 するため, 少ないTi量でも微細な等軸晶組織が得られた と推察される。

さらに結晶不整合度と $\delta$ 鉄の凝固核生成能の関係に従え ば，TiNと同じくらいSpinelにも $\delta$ 鉄の不均質核生成を促 進する作用があるはずである。このことを検証するため， 溶鋼の $\mathrm{N}$ 量を $0.003 \%$ まで低減し同様の溶解実験を行った。 その結果, Fig. 6に示すように低 Nの Spinel分散 16\% Cr$0.16 \%$ Ti 鋼法等軸晶凝固しなかった。Spinel が等軸晶凝固 


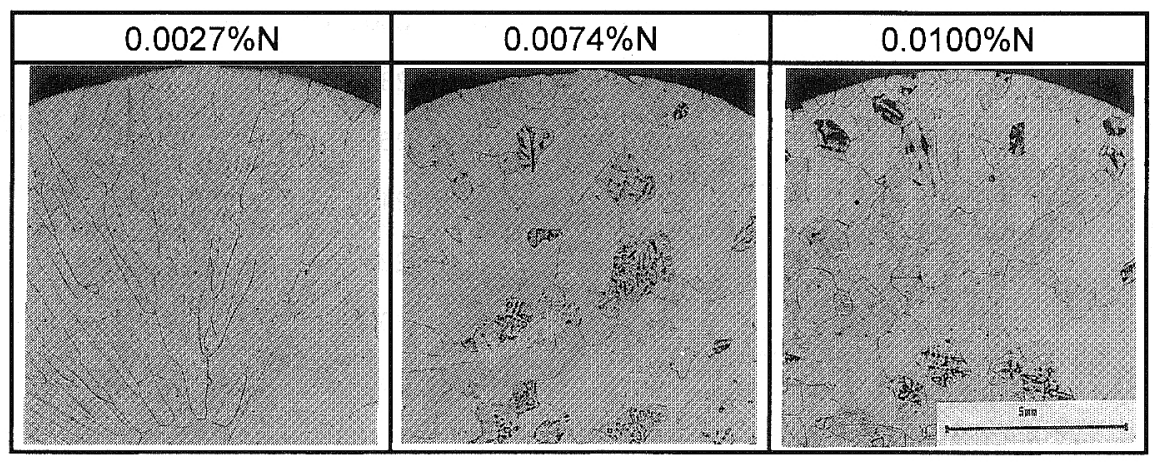

Fig. 6. Effect of $\mathrm{N}$ content on solidification structure of $16 \% \mathrm{Cr}-0.15 \% \mathrm{Ti}$ steel included Spinel particles, where spinel means inclusion with 0.3 to $0.5 \mathrm{Mg} / \mathrm{Al}$ mass ratio by EDS.

に有効でなかったのは，結晶不整合度以外に粒子サイズ ${ }^{13)}$ や化学的性質 ${ }^{14,15)}$ な゙゙の因子も凝固核生成能に影響を及ぼ すためと推察される。

\section{$4 \cdot 2 \mathrm{Al}-\mathrm{Mg}$ 系 Spinelの分散機構}

TiNの生成促進にはSpinelの存在が有効であるが，その ためには Spinel が溶鋼中に均一微細に核生成することが必 要である。ここでは，そのメカニズムについて考察する。

脱酸生成物の核生成機構については，次の考え方が有力 である。

(1) 脱酸剂の溶解過程で高脱酸元素濃度の部分で均質核生 成 ${ }^{16)}$

(2) 溶鋼中に分散した異質物質上に核生成

(3) 界面エネルギーの低い組成の核が生成，その後の成長 過程で組成変化 ${ }^{17}$

溶解試験 Bでは Al 無添加にて実騟したのにもかかわら ずSpinelが生成しているので，(1)の考え方では説明ができ ないし，また均一分散も望めない。(2)の考え方はTiNや $\delta \mathrm{Fe} の$ 核生成を説明するのに有力であるが, Spinelの核と なる化合物は現時点では観察されていない。

Spinel 住イン性結晶で融点が $2135^{\circ} \mathrm{C}$ と高く, 溶鋼との 界面エネルギーは $\mathrm{Al}_{2} \mathrm{O}_{3}{ }^{18)}$ と同じくらい大きいと推定され る。しかしながら， $\mathrm{Al}_{2} \mathrm{O}_{3}$ や $\mathrm{MgO}$ は Ti酸化物と複合酸化物 を形成することによりその融点が約 $1600^{\circ} \mathrm{C}$ まで低下する ことが計算状態図 ${ }^{19}$ Fig. 7により予测されている。また， 液相の Ti酸化物は溶鋼との界面エネルギーが非常に小さ

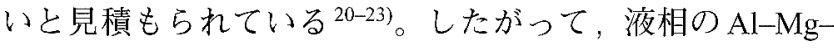
$\mathrm{Ti}$ 複合酸化物は二液相分離により均質椟生成するのに非常 に適している。そこでSpinel はいったんそのような $\mathrm{Al}$ $\mathrm{Mg}-\mathrm{Ti}$ 複合酸化物が均質核生成した後に成長する(3)の考え 方が最も有力である。そこで次にそのような酸化物の均質 核生成の可能性を検討する。

古典的核生成理論によれば，脱酸生成物が過飽和状態の 溶鋼から核生成するのに必要な自由エネルギー変化 $\Delta G^{*}$ および核の生成頻度 $I\left(\right.$ nuclei $\left./ \mathrm{mm}^{3} \cdot \mathrm{s}\right)$ は次式で示される。

$\Delta G^{*}=(16 / 3 \pi) \sigma^{3} / \Delta G v^{2}$

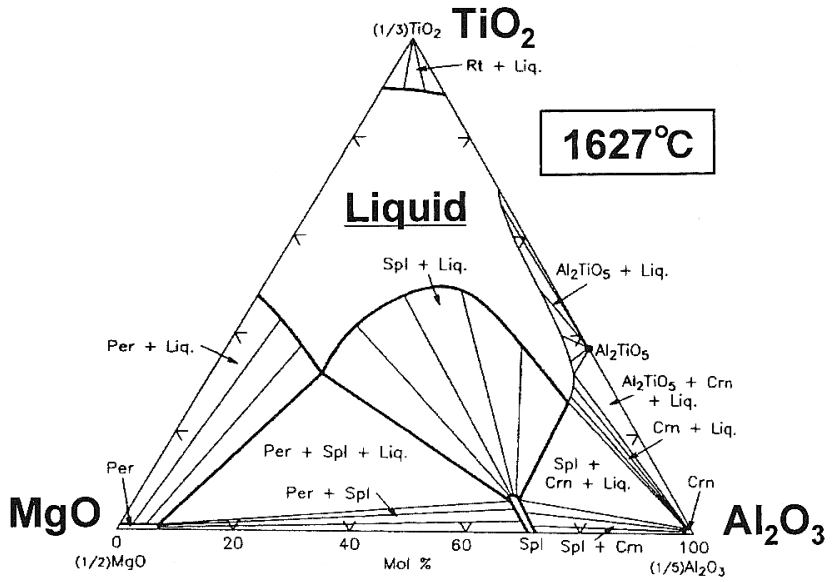

Fig. 7. Calculated phase diagram for the $\mathrm{Al}_{2} \mathrm{O}_{3}-\mathrm{MgO}$ $\mathrm{TiO}_{2}$ system at $1627^{\circ} \mathrm{C}$. ${ }^{19}$

Table 4. Calculated supersaturation degree $S^{*}$ for homogeneous nucleation.

\begin{tabular}{|c|c|c|c|}
\hline Inclusions & $V\left(\mathrm{~m}^{3} / \mathrm{g}\right.$-atom) & $\sigma(\mathrm{N} / \mathrm{m})$ & $S^{\star}$ \\
\hline \hline $\mathrm{TiN}$ & $0.58 \times 10^{-5}$ & 0.3 & 1.23 \\
\hline $\mathrm{TiO}$ (liq.) & $0.55 \times 10^{-5}$ & 0.1 & 1.04 \\
\hline $\mathrm{MgO}$ & $0.56 \times 10^{-5}$ & 1.6 & 11.3 \\
\hline $\mathrm{Spinel}$ & $0.57 \times 10^{-5}$ & 2.3 & 70.1 \\
\hline $\mathrm{Al}_{2} \mathrm{O}_{3}$ & $0.52 \times 10^{-5}$ & 2.3 & 48.3 \\
\hline $\begin{array}{c}\mathrm{Al}-\mathrm{Mg} \text {-Ti-oxide } \\
\text { (liq.) }\end{array}$ & $\begin{array}{l}0.57 \times 10^{-5} \\
\text { (estimated) }\end{array}$ & $\begin{array}{c}0.1 \\
\text { (estimated) }\end{array}$ & 1.04 \\
\hline
\end{tabular}

$V$ is the volume of inclusions per gram-atom.

$\sigma$ is the interfacial energy between inclusion and liquid Fe.

$$
I=A \exp \left(-\Delta G^{*} / k T\right)
$$

ここで， $\sigma$ は溶鋼－酸化物間の界面自由エネルギー， $\Delta G v$ は酸化物生成に伴う体積自由エネルギー変化，kはボルツ マン定数，A 頉度因子， $T$ は溶鋼温度である。核生成頻 度 $I か ゙ 1 の$ 場合の $\Delta G v^{*}$ おび $\Delta G v^{*}$ に対応する臨界過飽和 度 $S^{*}$ との関係は次式で示される。

$$
\Delta G \nu^{*}=-2.7\left(\sigma^{3} / k T \cdot \log A\right)^{1 / 2}=-(R T / V) \ln S^{*}
$$

ここで，Vは酸化物のグラム原子体積である。Aの值とし て $10^{21}$ を用いて，臨界過飽和度 $S^{*}$ を計算した。Table 4 に 


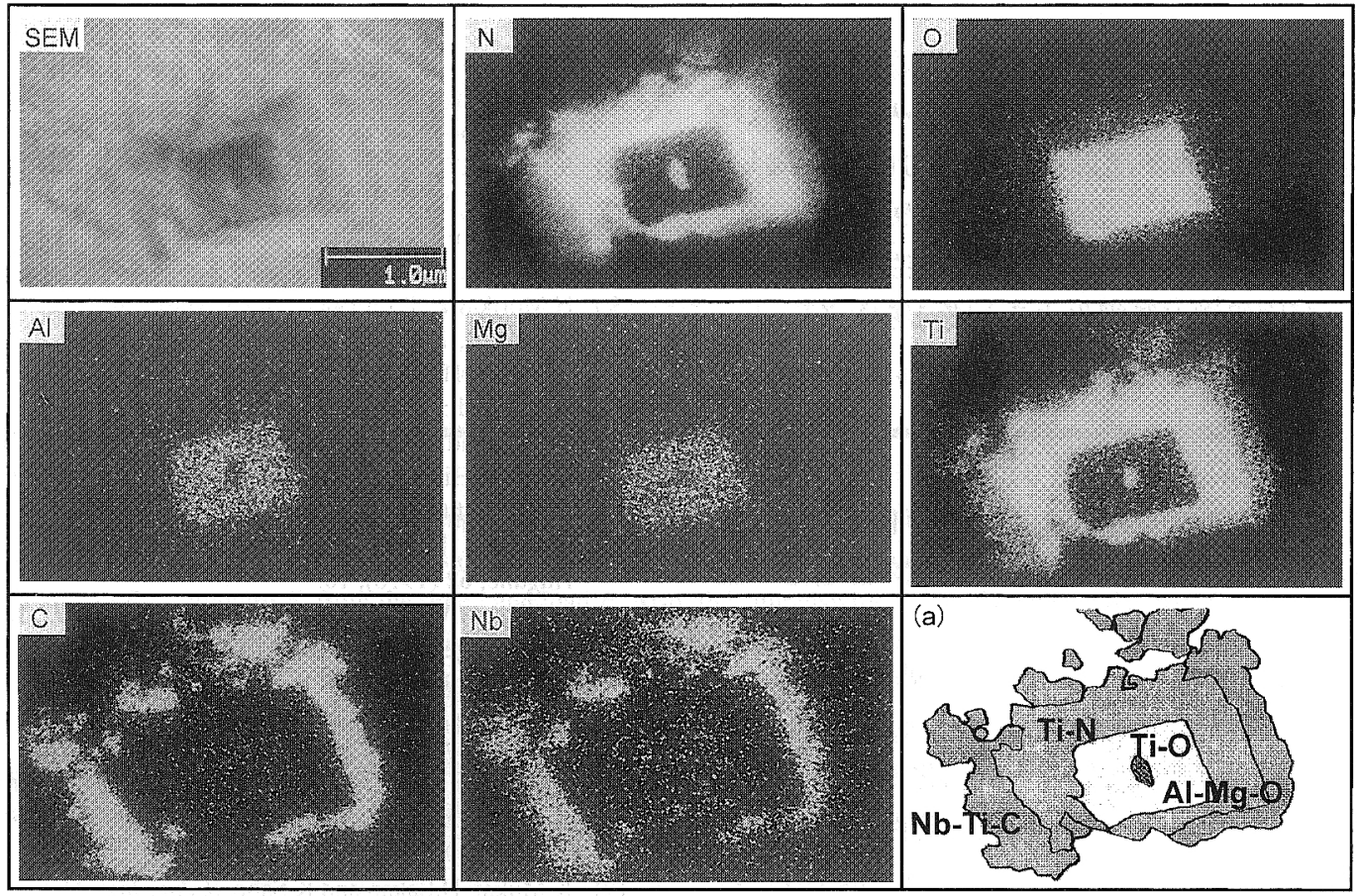

Fig. 8. SEM micrograph and Auger electron images of an inclusion in B2 steel. (a) Schematic view.

示すようにSpinel, $\mathrm{MgO}$ および $\mathrm{Al}_{2} \mathrm{O}_{3}$ が均質核生成するには 非常に大きな過飽和度が必要であるのに対し， Al-Mg-Ti 複合酸化物は容易に均質核生成すると予想される。した がって, Spinel を溶鋼中に均一微細に分散させるにには，兄 の核生成段階において Ti酸化物が必須であると推察され る。

Ti酸化物の関与を明らかにするため, 等軸晶凝固した鋼 B2に分散する介在物の微細構造をオージェ電子分光によ り解析した。その方法としては, 組織観察面をアルコール 中ダイヤモンド研磨し, 前处理として $\mathrm{Ar}^{+}$イオンスパッタ リングを施し, 加速電圧 $10 \mathrm{kV}$, 試料電流 $10 \mathrm{nA}$ の条件に て測定した。測定対象として酸化物とTiNの複合構造をし ている介在物4つを無作為に選択した。

Fig. 8に穴の内一つの複合介在物の SEM像，各元素マッ ピング像，および構造解析した結果を示す。マッピング像 から明らかなようにこの介在物は4層構造をしている。最 内層には $\mathrm{N}-\mathrm{O}-\mathrm{Ti}$ ，第2層には $\mathrm{Al}-\mathrm{Mg}-\mathrm{O}$, 第3層には $\mathrm{N}-\mathrm{Ti}$, 最外層には $\mathrm{C}-\mathrm{N}-\mathrm{Nb}-\mathrm{Ti}$ が検出された。 $\mathrm{N}$ 元素のマッピン グ像によると，中心部にはN 強度が強いことを示している が，オージェピークに扔いてN $389 \mathrm{eV}$ と Ti $390 \mathrm{eV}$ との分

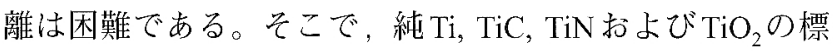
準試料を用いたオージェスペクトルから，Fig. 9に示す Ti

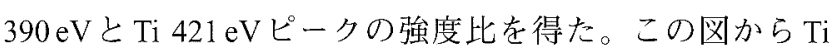
結合状態によりその強度比は異なることがわかった。複合 介在物の中心部は，穴の強度比が $56 \%$ であることから， Ti 酸化物と判定した。なお，他の3つの複合介在物にはTi酸 化物は存在しなかった。観察されたTi酸化物は, 恐らく $\mathrm{Al}-\mathrm{Mg}-\mathrm{T}$ 複合酸化物が晶出した後, Al-Mg系 Spinel との

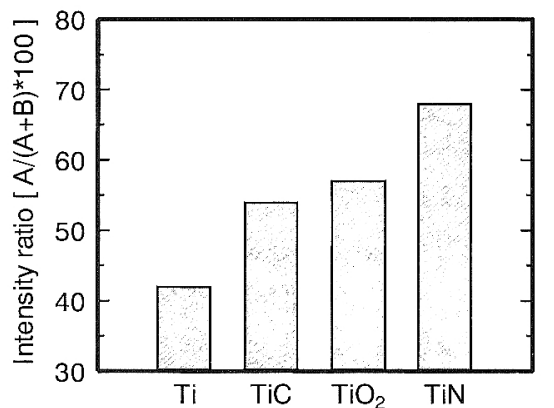

Fig. 9. Intensity ratio of AES spectra, A (Ti $390 \mathrm{eV})$ and $\mathrm{B}(\mathrm{Ti} 421 \mathrm{eV})$.

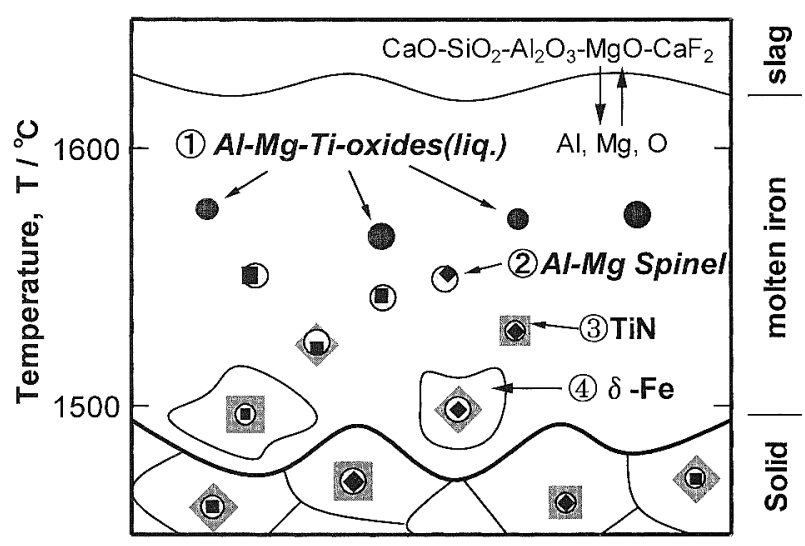

Fig. 10. Schematic illustration of equiaxed crystals solidification in $16 \% \mathrm{Cr}$ ferritic stainless steel assisted by inclusions.

相分離により晶出したものと推察される。この観察結果は, 前記の核生成の考察を支持するものと判断される。

以上の考察より, 酸化物分散から等軸晶凝固までの過程 
をFig. 10の模式図に沿って説明する。まず，スラグ精錬 により溶鋼酸素ポテンシャルが下がり, $\mathrm{Mg}$ がスラグおよ びるつぼから溶出する ${ }^{24)}$ 。次いで, 界面エネルギーの低い $\mathrm{Al}-\mathrm{Mg}-\mathrm{Ti}$ 複合酸化物融体が溶鋼中に自発的に核生成し, その後の成長過程で Spinel が晶出する。その Spinel が TiN 晶出を促進し, さらにその TiNが Fe凝固の核生成物質とし て働いた結果，凝固組織が微細化すると考えられる。

\section{5. 結言}

$16 \mathrm{mass} \% \mathrm{Cr}-0.15 \mathrm{mass} \% \mathrm{Ti}-0.009 \% \mathrm{mass} \% \mathrm{~N}$ 含有フエライト ステンレス鋼の凝固組織に及ぼす酸化物組成の影響を調査 した。

(i) 鋳片中の酸化物はTiNに覆われた状態で観察され， $\mathrm{Al}$ と $\mathrm{Mg}$ を含有していた。その酸化物中の $\mathrm{Mg} / \mathrm{Al}$ 重量比が 0.3 から 0.5 の時, 凝固組織は等軸晶微細化した。 $\mathrm{Al}_{2} \mathrm{O}_{3}$ $\mathrm{MgO}$ 系状態図によると, その酸化物組成範囲は溶鋼温度 付近における Spinelのものと一致する。Spinel は TiNとの 結晶不整合度が小さいため, TiNの晶出を促進し，その結 果凝固組織が微細化したと推察される。

(ii) 溶鋼中におけるSpinelの分散機構は，いったん界面 エネルギーの低い $\mathrm{Al}-\mathrm{Mg}-\mathrm{Ti}$ 系複合酸化物融体が溶鋼中に 自発的に核生成し，その後の成長過程でSpinelが晶出する と考察した。

\section{文献}

1) M.Matsuo: Bull. Jpn. Inst. Met., 19 (1980), 192.

2 ) H.Takeuchi, H.Mori, Y.Ikehara, T.Komano and T.Yanai: Tetsu-toHagané, 66 (1980), 38.

3 ) Y.Itoh, S.Takao, T.Okajima and K.Tashiro: Tetsu-to-Hagané, 66 (1980), 110.

4 ) I.Takahashi, K.Mineura, T.Sudo and S.Yoshida: Nippon Stainless Tech. Rep., 20 (1985), 45.

5 ) H.Morikawa, T.Yamauchi and M.Hasegawa: Nisshin Steel Tech. Rep., 57 (1987), 1.

6 ) T.Koseki, H.Inoue and M.Fuji: CAMP-ISIJ, 11 (1998), 530.

7 ) B.Hallstedt: J. Am. Ceram. Soc., 75 (1992), 1497.

8 ) H.Ohta and H.Suito: Metall. Mater. Trans. B, 28B (1997), 1131.

9 ) H.Ito, M.Hino and S.Ban-ya: Tetsu-to-Hagané, 84 (1998), 1.

10) B.L.Bramfitt: Metall. Trans., 1 (1970), 1987.

11) T.Ohashi, K.Hiromoto, H.Fujii, Y.Nuri and K.Asano: Tetsu-toHagané, 62 (1976), 10.

12) H.Ohta, G.V.Pervushin and H.Suito: CAMP-ISIJ, 13 (2000), 1288

13) Y.Morikage, K.Ooi, F.Kawabata and K.Amano: CAMP-ISIJ, 10 (1997), 1309.

14) B.E.Sundquist and L.F.Mondolfo: Trans. Metall. Soc. AIME, 221 (1961), 607.

15) M.Mizuno, I.Tanaka and H.Adachi: Acta Mater, 46 (1998), 1637.

16) Y.Kojima, K.Takahashi, H.Sakao and K.Sano: Tetsu-to-Hagané, 53 (1967), 589.

17) K.Mukai, H.Sakao and K.Sano: J. Jpn. Inst. Met., 32 (1968), 1143.

18) B.C.Allen and W.D.Kingery: Trans. Metall. Soc. AIME, 215 (1959), 30.

19) L.Kaufman: Physica B +C, 150 (1988), 99.

20) P.Kritsalis, B.Drevet and N.Eustathopoulos: Scr. Metall. Mater., 30 (1994), 1127.

21) X.B.Zhou and J.Th.M.DeHosson: Acta Mater., 44 (1996), 421.

22) K.Oikawa, K.Ishida and T.Nishizawa: ISIJ Int., 37 (1997), 332.

23) T.Nishizawa: ISIJ Int., 40 (2000), 1269.

24) T.Nishi and K.Shinme: Tetsu-to-Hagané, 84 (1998),13. 